\title{
Sciendo
}

\section{Selection of Project Managers: An Overview}

\author{
Marija Šiško Kuliš \\ University of Rijeka, Faculty of Economics and Business, Rijeka, Croatia
}

\begin{abstract}
Background: The project manager choice is one of the most important, complicated and multi-layered decisions in project management. Although the competence of a project manager is the subject of numerous studies, mostly in the field of economic sciences, there are still relatively few studies dealing with project manager selection. Objectives: The aim of this paper is to provide a useful overview of research on approaches, models, techniques, and competencies during the process of selecting project managers, in order to improve understanding an effective process of selecting project managers from academic researchers and practitioners' point of view. Methods/Approach: This article is a scientific review of previously published studies that are linked to competencies of a project manager and the process of project manager selection according to the traditional and the modern approach. Results: The process of selecting project managers is not sufficiently investigated in Croatia, while most of the research is focused to traditional approach. Conclusions: In this work, we propose a combination of the traditional and the modern approach to the selection of project managers, which would be based on the multicriteria decision making.
\end{abstract}

Keywords: manager, project, approach, competence, model, criterion JEL classification: L21, M21, M 54

Paper type: Research Paper

Received: Aug 5, 2020

Accepted: Sep 10, 2020

Citation: Šiško Kuliš, M. (2020), "Selection of Project Managers: An Overview", Business Systems Research, Vol. 11, No. 2, pp. 99-116.

DOI: 10.2478/bsrj-2020-0018

\section{Introduction}

The history of human achievement is marked by projects as unique, one-time, timelimited, goal-oriented creative processes, from the creation of the Bible, the construction of the Egyptian pyramids and the Great Wall of China, space conquest projects, new energy sources, new materials, biotechnology projects and new institutions. Other less exposed projects that have guided and are directing the development of humanity (Tainter, 2007). Likewise, today's time is marked with projects. Moreover, the trend of increasing the number of projects is evident in the scientific, economic, social and political environment (Barnes, 1988). However, most of these projects fail, the project results are mostly devastating (El-Saaba, 2001; Faniran et al., 2000). It is alarming that, according to data from the relevant literature: $52.7 \%$ of projects fail to close on time and it turns out that only $30 \%$ of projects are carried 
out so that they meet all projected goals (Nahod, 2014, Uhlir, 2011). The aforementioned well determines Cobb's Paradox: „We know why projects fail. We know how to prevent their failure. So why do they still fail?" (Cobb, 1995).

According to Morris and Hough (1987), Clancy (2008), Boetcher (2008), Greer (1999) the critical project success factors are: clearly defined project goals, project sponsor strategy, project coverage, technological complexity, simultaneity, contracting strategy, project environment, top management support, geophysical conditions and human resources competence. Among them, the competence of the project manager should certainly be emphasized as a critical factor of project success (Morris \& Pinto, 2007; Meredith \& Mantel, 2003; Muller \& Turner, 2007; Wang et al., 2005; Varajão \& Cruz-Cunha, 2013).

The project manager is accountable for the project success (Afshari et al., 2018), and according to global predictions, the most important job of the 21st century will be the project manager (Stewart, 1999). Therefore, his choice is the prime decision in project management (Varajão \& Cruz-Cunha, 2013; Rashid et al., 2018) and the topic worth exploring (Smith, 2013a). From the aspects of the project manager selection, it should be emphasized (Sadatrasool et al., 2016):

- The project manager has special responsibility for fulfilling all defined project goals inside the prescribed deadlines and the set budget.

- He manages the project every day. Project managers contributors, with responsibilities for the project certain parts, can significantly support it without compromising its credibility and responsibility.

- The project manager should demonstrate competencies, which include tacit and explicit knowledge, skills and proportionally experience with the scope, complexity and project risks.

For the project manager to achieve authority and/or reputation the towards project team and stakeholders, essential is to pass the project manager selection process. It is an internal or public selection and selection process. Credibility should be professional or administrative (Omazić \& Baljkas, 2005). Professional credibility means that the project manager does not have to be an expert, nor does he have to know more in all areas of activity than any team member does; he only has to understand the technological process of the project. Administrative credibility refers to the fact that the project manager should be achieved that the project proceeds according to the schedule, Inside the budget and within the deadline frame in which it is provided, and should provide key resources for project development.

Project management is not easy and is demanding and stressful for the project manager because it implies the need for more comparative competencies. Selecting the best project manager is a complicated process because there are many topics to consider. The process of weighting the criteria relative to the project manager selection is particularly sensitive. It is necessary to ensure that the selected project manager has a balanced relationship of knowledge, experience and personality traits (Varajão \& Cruz-Cunha, 2013). This has stimulated interest in developing the body of knowledge and certification procedures that can be used to assess, recognize, and as a guide to developing project management competencies (Crawford, 2000).

However, when it comes to the results of relevant researches, there is a certain imbalance here: on the one hand, searching databases such as Scopus\&Web of Science, Econlit, etc. Numerous research addressing desirable project manager attributes can be found (Meredith \& Mantel, 2003), including their moderation impact on project success (Papke-Shields et al., 2010; Tesch et al., 2003). On the other side, there are only a few types of research about the selection of a project manager (Smith, 2013a; Smith, 2013b). Besides, recent research on this topic comes mainly from 
the field of information technology, sometimes engineering and very rarely from the field of economics, although the consequences of poor selection of project managers are first seen in the economic dimensions of project success. The process of selecting project managers is insufficiently researched and it has consequences on the state of knowledge for this topic and at practice, especially in Croatia.

The aims of this paper are: (i) to provides a useful overview of research on approaches, models, techniques, and competencies during the project manager selection process, (ii) to improve understanding and effectiveness of the process of selecting project managers from academic research and practitioners point of view, (iii) to make a good framework for new research in this insufficiently researched discipline and encourage explorers to explore this topic, (d) to contribute to the development state of knowledge for this topic and practical implementation in Croatia.

This article is composed in the following manner. After the introduction, section two briefly describes the state of knowledge in the field of a topic in Croatia. The third section focuses on existing studies of (a) Competence of the project manager, (b) Project manager selection that includes two parts traditional approach and modern approach - multi-criteria decision making. The last section displays conclusions and recommendations for future researches.

\section{Competence of the project manager}

The results of numerous studies show that the project manager's competence is a project success key factor (Gonzales \& Terriquez, 2013). Project managers are classified as stars, creative experts, decision-makers, insensitive pragmatists (Hauschildt et al., 2000). An effective project manager should be above average intelligent and have exceptional problem-solving skills (Ress et al., 1996). However, there is no consensus on what competencies a successful project manager should have. Although some researchers believe that the competencies of project managers are generic, the prevailing view is that different projects need different competencies. In this atmosphere, the interest of scientists and business people to determine the critical and key competencies of project managers that will imply the success of the project is growing. The internal and external environment of the project is most often changeable, which requires continuous improvement of the competence of the project manager (Takey \& Carvalho, 2015). A review of research competences of the project manager is given in Table 1. The emphasis is on projects in the field of construction, of which the electricity sector is a part.

Table 1

Overview of research-project manager competencies

\begin{tabular}{ll}
\hline \multicolumn{1}{c}{ Research } & \multicolumn{1}{c}{ Project manager competencies } \\
\hline & Competencies related to the personality of the project manager: \\
Omidvar et al. & characteristics; Job orientation: Targeted performance (compliance \\
(2011) & with standards); Contextual competences: competences related to \\
& the environment client, organization, subcontractors and suppliers, \\
& competencies. \\
& Technical skills, site management and mobilization, assessment and \\
tendering, design of Gantt charts and environments, technical \\
literacy, public relations (PR), the delegation of tasks, conducting \\
meetings, contracting, and technical literacy.
\end{tabular}




\begin{tabular}{|c|c|}
\hline $\begin{array}{l}\text { Edum- } \\
\text { Fotwe\&McCaffer } \\
(2000)\end{array}$ & $\begin{array}{l}\text { Technical skills, mobilization, site management, assessment and public } \\
\text { tender, time and environment management (Gantt Chart), } \\
\text { technical, presentation and report literacy, decision making, } \\
\text { negotiation skills, job delegation, teamwork, IT skills and oratory skills, } \\
\text { report literacy, meeting and stress management, public relations, } \\
\text { marketing and sales, problem-solving. }\end{array}$ \\
\hline El Saba (2001) & $\begin{array}{l}\text { Technical skills, IT skills, coping in unfamiliar situations, job delegation, } \\
\text { mobilization, problem orientation, holistic view of the project, project } \\
\text { relationship management with industry, public opinion, knowledge of } \\
\text { PM methods, tools and techniques, technological skills, objectives } \\
\text { orientation, political flexibility, planning, organization, self-confidence. }\end{array}$ \\
\hline Odusami (2002) & $\begin{array}{l}\text { Technical (hard) and soft skills, troubleshooting, decision } \\
\text { management, teamwork, job delegation, stress resistance. }\end{array}$ \\
\hline Frank (2002) & $\begin{array}{l}\text { Character traits and background: education, faithfulness, tacit and } \\
\text { explicit knowledge, ambition, intelligence, visionary, analytical } \\
\text { managing people and the environment, be a leader, emotiona } \\
\text { stability. Professionalism: effectiveness, to have a vision, target- } \\
\text { oriented, analytical skills, to be fast, inspired, leadership. Project skills } \\
\text { execution, methodology, initiation, selection, control, time and } \\
\text { documentation management. Core competencies of the project } \\
\text { manager: honesty, goal orientation, professionalism, analytical skills. }\end{array}$ \\
\hline Loo (2003) & $\begin{array}{l}\text { Technical skills, human competencies, team management, } \\
\text { stakeholder management, conflict management, motivation, } \\
\text { organizational effectiveness. }\end{array}$ \\
\hline $\begin{array}{l}\text { Pant \& Baroudi } \\
(2007)\end{array}$ & $\begin{array}{l}\text { Communication of team and project stakeholders, interpersonal skills, } \\
\text { technical competencies, cognitive abilities to understand situations, } \\
\text { organizational effectiveness, flexibility, decision making, problem- } \\
\text { solving, trustworthiness. }\end{array}$ \\
\hline $\begin{array}{l}\text { Tohidi \& Jabbari } \\
\text { (2012) }\end{array}$ & $\begin{array}{l}\text { Team motivation, fair attitude towards the environment, leadership, } \\
\text { regular conditions, correct attitude towards co-workers, human } \\
\text { resources development. }\end{array}$ \\
\hline Madter et al. (2012) & $\begin{array}{l}\text { Teamwork, human management and develop their competence, } \\
\text { self-confidence, customer orientation, communication ability, } \\
\text { interpersonal skills, understanding, conflict and change } \\
\text { management, organizational support, looking opportunities for } \\
\text { improvement, value management. }\end{array}$ \\
\hline Brière et al. (2015) & $\begin{array}{l}\text { Flexibility, stakeholder management, management ano } \\
\text { communication skills, personality, interpersonal skills, ethics, leadership } \\
\text { skills, change management. }\end{array}$ \\
\hline
\end{tabular}

Source: Authors' work

To identify the project manager competencies and to provide guidelines for the continual growth of the basic competencies for project management, 2.

Table 2

Comparative analysis of the competence framework of the project manager

\begin{tabular}{llll}
\hline \multicolumn{1}{c}{ PMI, 2007 } & \multicolumn{1}{c}{ IPMA, 2015 } & \multicolumn{1}{c}{ APM, 2015 } \\
\hline Behavioural & 6 personal and & 10 personal and & In three dimensions \\
competencies & social competencies & social & (constructs): behavioural, \\
& & competencies & managerial and \\
& & contextual competencies, \\
& & 27 competencies were \\
& & nominated, e.g. \\
& & leadership. \\
& & They are combined. \\
\hline
\end{tabular}




\begin{tabular}{|c|c|c|c|}
\hline $\begin{array}{l}\text { Technical } \\
\text { competencies }\end{array}$ & $\begin{array}{l}\text { Technical } \\
\text { competencies are } \\
\text { considered "other } \\
\text { competencies", and } \\
\text { the PMCD does not } \\
\text { address specific } \\
\text { competencies. }\end{array}$ & $\begin{array}{l}20 \text { hard } \\
\text { competencies are } \\
\text { nominated. }\end{array}$ & $\begin{array}{l}\text { Technical competencies } \\
\text { are related to the } \\
\text { integration of design work } \\
\text { and production of project } \\
\text { results. }\end{array}$ \\
\hline $\begin{array}{l}\text { Management } \\
\text { competencies }\end{array}$ & $\begin{array}{l}\text { Knowledge: } \\
\text { Knowledge of the } \\
\text { project manager } \\
\text { about the processes, } \\
\text { tools and techniques } \\
\text { for project } \\
\text { management. } \\
\text { Performance: This is } \\
\text { the application of } \\
\text { project } \\
\text { management } \\
\text { knowledge. In } \\
\text { general, what } \\
\text { project manager is } \\
\text { capable of } \\
\text { achieving with his } \\
\text { knowledge? }\end{array}$ & $\begin{array}{l}\text { Practical } \\
\text { competencies: } \\
\text { fourteen } \\
\text { competencies } \\
\text { related to the areas } \\
\text { of knowledge about } \\
\text { projects, programs } \\
\text { and portfolios and } \\
\text { project } \\
\text { management } \\
\text { processes. }\end{array}$ & $\begin{array}{l}\text { Among the } 27 \text { established } \\
\text { competencies, there is a } \\
\text { combination of } \\
\text { behavioural, } \\
\text { management, and } \\
\text { contextual competencies. } \\
\text { Some of APM's } \\
\text { responsibilities are related } \\
\text { to areas of knowledge } \\
\text { about project } \\
\text { management and project } \\
\text { management processes, } \\
\text { such as procurement, } \\
\text { scheduling and risk } \\
\text { management. }\end{array}$ \\
\hline $\begin{array}{l}\text { Contextual } \\
\text { competencies }\end{array}$ & $\begin{array}{l}\text { Contextual } \\
\text { competencies are } \\
\text { treated as } \\
\text { secondary } \\
\text { competencies that } \\
\text { the PMCD does not } \\
\text { deal, but supports } \\
\text { their importance } \\
\text { within the } \\
\text { organization. }\end{array}$ & $\begin{array}{l}\text { Perspective } \\
\text { competencies: five } \\
\text { competencies } \\
\text { linked to the project } \\
\text { management: } \\
\text { strategy, standards, } \\
\text { recommendations } \\
\text { and regulations, } \\
\text { process structures, } \\
\text { management, } \\
\text { compliance, } \\
\text { supremacy and } \\
\text { interest aspect, } \\
\text { ethics and cultural } \\
\text { aspect. }\end{array}$ & $\begin{array}{l}\text { More than } 27 \text { nominated } \\
\text { competencies; there is a } \\
\text { compound of } \\
\text { management, } \\
\text { behavioural, } t \text {, and } \\
\text { contextual competencies. } \\
\text { For example, control } \\
\text { methods are one of the } \\
\text { APM competencies. }\end{array}$ \\
\hline
\end{tabular}

Source: Authors' work

Relevant international professional project management associations have developed project management guides and project manager certification. Globally, the best known and most numerous are PMI (Project Management Institute), IPMA (International Project Management Association) and APM (Association for Project Management). There are still many national and international associations working on the professionalization of project management by a competency approach. A brief comparison of the project manager competency framework is given in Table 2.

The international associations IPMA and PMI have the head role at Europe and their main goals are to lead the mainstreaming of project management so they have developed their frameworks and procedures for assessing the project manager competence, Moon et al (2018), for certification of project, program and portfolio managers. Certification is following the standard ISO / IEC 17024: 2012 It is deployed by the ISO Committee on conformity assessment and approved by both ISO and the IEC (International Electrotechnical Commission). 
Certification of managers carried out in Croatia by subsidiaries of IPMA and PM institutions. Important is to point out that there are more than a million certified project managers worldwide (a number collected from statistics on PMI.org and IPMA.org), according to Farashah et al. (2018). There is an increasingly pronounced trend of increasing certified project managers in Croatia too (Uhlir, 2013).

Managers who have validated their competencies through certifications will certainly lead to better results in less time and at a lower cost than those project managers who are not allowed to validate their competencies with certifications.

\section{Traditional approach}

Traditionally, potential candidates for project manager position are selected in a three-step process that includes resume review, interview and reference check (Horner, 2010; Smith, 2013a) after which a decision is made on the selection of candidates.

The interview plays a major role in this approach and its main comparative advantage is the value of the personal contact it provides. The primary goal of the interview is to project the candidate's behaviour in new and unknown situations inside role frame of the project manager. The secondary goal is to inform the candidate about the role he is applying for (Armstrong, 2009).

Recent research shows that interview validity is enhanced by structured interviews that achieve greater validity than unstructured ones (Macan, 2009), as shown by the results of the global researches (Smith, 2013a) which show that project stakeholders are significantly more satisfied with the application of structured interviews in project manager selection, than the classic three-step approach.

As already mentioned, there is a little number of researches related to the project manager selection, and below is a brief overview of such research found in the relevant research databases.

Swanson (1964), this early research showed that the selection process can be understood and described, but did not discuss an approach that could be applied in the process of efficient and effective project manager selection.

Collins (1998) focused his research on selecting a project manager within an organization. The starting point of his research was that the project manager should be mastered technical and managerial skills to be "successful". As it was assumed that the candidate was already a member of the organization, Collins 'research did not include consideration of the recruitment process, within which data were to be obtained to better understand the candidate, such as resume review and verification of relevant references.

Namely, human species cognitive processes and assessments are biased, imprecise, and multifaceted. Traditional methods of choosing leaders are inefficient and ineffective because they neglect the aforementioned (Rashidi et al., 2011).

Smith (2013a) who says that the traditional selection of project managers is usually based on a review and verification of the nominated references, curriculum vitae and interviews hold a similar view. This three-step selection process has not changed for many years. Given the progress in understanding the role of the leader and the influence of the project leader on the success of the project, this selection process is unsatisfactory. Besides, with the traditional approach of selecting a project manager, the weighting of individual characteristics of the project manager may be questionable. The selection process becomes more difficult when there are several qualified candidates. There is also the possibility of disagreement among board members regarding the selection of a particular person, especially when there are multiple qualified project managers. In such cases, a computational system based on 
artificial intelligence, which can support the decision-making process, is very useful. (Rashidi et al., 2011).

Horner (2010) the traditional three-step approach to project manager selection is not comprehensive enough to allow the determination of respondents 'potential for the project manager role. The traditional three-step approach to project manager selection is mostly inaccurate, biased, is not unique and has a thin accuracy.

More recently, certain researchers have advocated psychometric testing as a model for the project manager selection process, for example, Aretoulis et al. (2009), Muchinsky (1979), and consider it more effective than the interviews of Korres et al. (2003). Namely, experience and hard competencies can be assessed and confirmed by someone's curriculum vitae. However, interpersonal and communication skills are hard to assess from someone's resume. It is necessary to implement specific psychometrics methods and techniques for research, evaluation of personality traits of the candidate for the project manager and thus precisely define his psychological profile. It should be emphasized that not only standard questionnaires are used, but also it is necessary to use relevant statistical methods such as synthesis and analysis method (Muchinsky, 1979).

On the other hand, Wolf (2005) considers it a controversial process with questionable results.

Besides, proponents of psychometric testing ignore the fact that behavioural competencies are also examined during the project management certification process and that such testing could easily become an end in itself. Besides, it could further complicate, prolong and increase the cost of the project manager selection process.

\section{Modern approach - multi-criteria decision making}

Advances in information technology over the last decade have shed new light on the project manager selection process. Thus, Afshari et al. (2018) emphasize that the project manager selection procedure should be based on Multi-Criteria Decision Making (MCDM). Data and information obtained by the selection process of the project manager are processed by precise mathematical models, which result in the selection of the most qualified person (Rashidi et al., 2011).

In the field of multicriteria decision-making, there are two types of multicriteria problems from the aspect of describing them with a mathematical model. These are (Tudela et al., 2006; Farahani et al., 2010):

- Multi-Objective Decision Making (MODM) is essentially a mathematical optimization that is effective for a scenario that can be seen as complex but at the same time well-structured problems. Structured in the mentioned context means a known initial and final state. Modelling includes a large number of variant solutions that have obvious limitations.

- Multi-Attribute Decision Making (MADM) or Multi-Criteria Analysis (MCA), which applies to a scenario characterized by the following: complex, complicated and vaguely defined objectives, high uncertainty and instability. Even during the solution process, the very nature of the problem changes, which further complicates the process of its effective solution. This type of problem is nominated as poorly structured problems.

- Multicriteria analysis methods include several methods such as dominance method, max-min, min-max, conjunctive and disjunctive method, lexicographic method, simple additive weighting SAW method (Simple Additive Weighting), VIKOR (Serbian/Croatian, VIšekriterijsko KOmpromisno Rangiranje) TOPSIS method (Technique for Order Preference by Similarity to Ideal Solution). 
Multicriteria analysis can be determined as a decision model that includes the following (Hajkowicz, 2009):

- Solutions set (variants which will be classified, ranked and evaluated by the person who has mandatory to make the decision).

- Criteria's set (mostly multidimensional criteria, which can therefore only be evaluated by different units of measurement).

- Values (evaluation) of each variant according to each criterion.

Multi-criteria analysis is an appraisal method that ranks solution variants and determines the overall evaluation of variants based on a set of pre-set criteria. Here, each variant is evaluated according to each of the set criteria (attribute) using the assigned weight (ponder) (Tudela et al., 2006).

The methodology for applying multicriteria analysis includes the following algorithm (Farahani et al., 2010): analyse multiple solutions, nominate criteria, evaluate solutions according to all criteria, determine the weights of the criteria, ordering and grouping solutions, make sensitivity analysis, and judge and finally decide.

In the project manager selection, the application of multicriteria analysis using Cloud Theory, which is based on a combination of Fuzzy sets, Gray Systems Theory, probability theory and statistical methods, is becoming more and more prominent (Baykasoğlu \& Özbakir, 2007; Chen \& Cheng, 2005; Lav et al., 2006; Sadatrasoola et al., 2016; Zavadskas et al., 2008). For example:

- SAW - Simple Additive Weighting (Hwang et al., 2007; Sivilevicius et al., 2008);

- TOPSIS - Technique for Order Preference by Similarity to Ideal Solution (Farahani et al., 2010; Varajao and Cruz-Cunha, 2013);

- VIKOR - Compromise Ranking Method (Kosijer et al., 2012; Šarka et al., 2008);

- COPRAS - Complex Proportional Assessment (Šarka et al., 2008, Karbass \& Nollet, 2008; Sliogeriene et al., 2009; Datta et al., 2009; Tupenaite et al., 2010);

- AHP Analytic Hierarchy Process (Yang \& Chou, 2011; Varajao \& Cruz-Cunha, 2013).

Figure 1

TOPSIS- basic concept

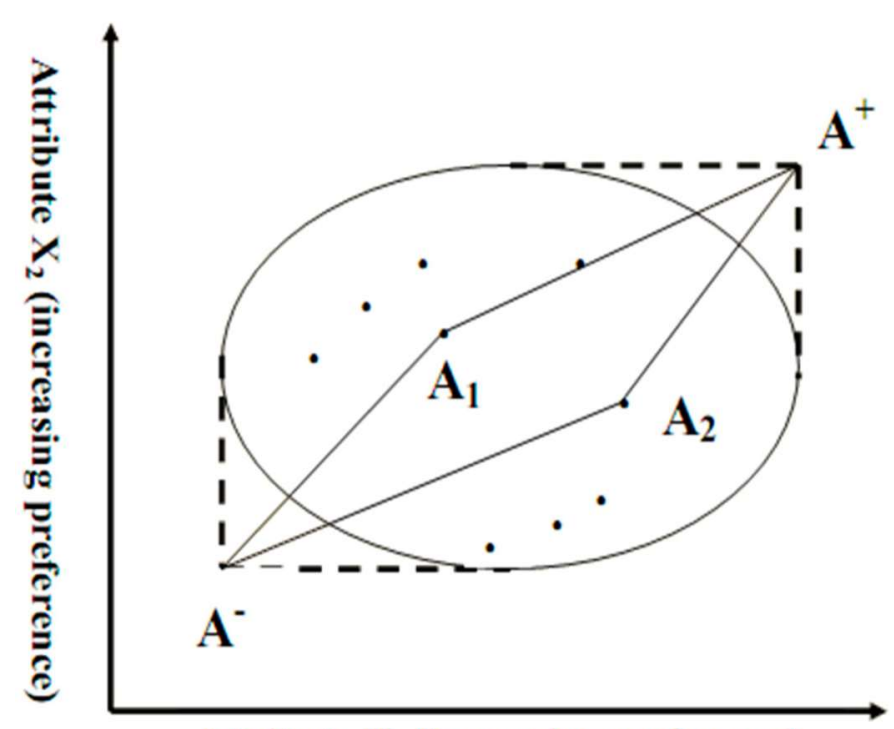

Attribute $\mathrm{X}_{1}$ (increasing preference)

Source: Balioti et al. (2018) 
The following is a brief description of these methods, which are relatively often used in economics, with special emphasis on AHP, which is still most often used in the project managers' selection:

- SAW is an additive method, the oldest, by far known and most widely used method. It is based on the integration of criterion values and weights into one size.

- COPRAS is used for multicriteria evaluation, maximizing, and minimizing criterion values. This method has a significant advantage over the SAW method: during data processing, i.e. multi-criteria evaluation, a calculation is performed for the maximum and minimum value of the observed criterion.

- TOPSIS is developed by Yoon and Hwang (1995). Optimization is done by looking for a solution that is the shortest way from the best solution and the longest away from the worst solution, as shown in Figure 1 (Balioti et al., 2018).

- Serafin Opricović first developed VIKOR, during his research work as part of his doctoral dissertation in 1979, and in 1980, it was first published in the article Duckstein \& Opricović where the acronym VIKOR was also used for the first time. This method is based on the optimization of conflicting criteria and the reference point is an ideal welcome in the observed functional space. The solution that is closest to the ideal is chosen and because of the procedure, it is called compromise (Kosijer et al., 2012).

- Analytic Hierarchy Process (AHP) is a very simple and therefore relatively most often implemented method for solving real problems where it is necessary to make a concrete decision in a real environment (Saaty, 1980, 2008). The name of the method describes its principles: (a) The word analyst refers to the dismantling of the problem to its building blocks; (b) The word hierarchy shows that the building blocks are arranged in sequence relative to the underlying goal; (c) The word process means that there are input and output data that are processed between these two points.

- The main advantage of this method is the ability of the decision-maker to compare alternatives. This is applied in several real-world situations (selection of contractors, selection of project managers, evaluation of project performance, hiring of new employees) where the relative importance is determined on-road scales that have structurally higher hierarchical levels (Al-Harbi, 2001; Kwak \& Anbari, 2009; Saaty \& Vargas, 2006; Wen-Yau, 2003). The application of AHP in the process of selecting project managers has been mentioned in several papers (Varajao \& Cruz-Cunha, 2013), and it has been applied in employment (Hsiao et al., 2011). AHP consists of three main constructions (Varajao \& CruzCunha, 2013): (1) Problem nomination and main goal, (2) Defining a hierarchical tree of criteria on which a weight is determined for each criterion, (3) Comparison of all possible solutions.

An example of a hierarchical tree of criteria is given in Figure 2. At the second level, there are three main criteria with individual weights whose total sum should be 1000 . Each of the main criteria combines its own set of sub-criteria and the sum of their weights must be 1000 (Varajao \& Cruz-Cunha, 2013). 
Figure 2

AHP - Hierarchical Criteria Tree

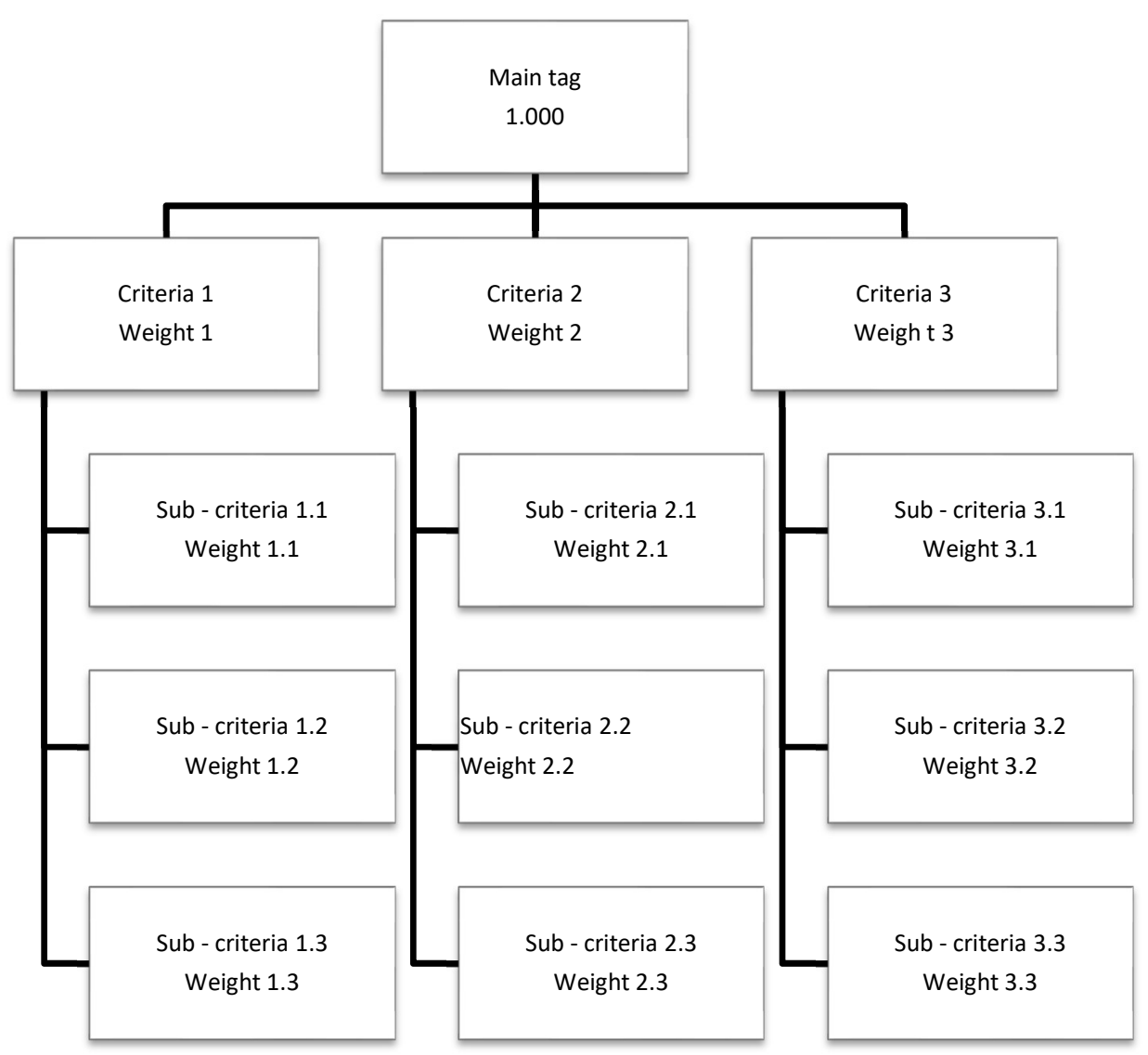

Source: Varajao and Crus-Cunha (2013)

AHP is used in different situations to make certain decisions. Examples of these situations are (Saaty, 2008) as the following.

- In 2001, the method was implemented to locate the optimal new position the Adapazari, Turkish city, after the earthquake.

- In 1998, applied in the selection procedure of the best offer for the multimedia system delivery of for the British Airways fleet.

- The process was applied in the conflict between the US and China over intellectual property rights in 1995 when Chinese citizens copied music, videos and CDs. The AHP analysis, which included hierarchies benefit three, charge and danger, showed that it is better for the United States side do not permission to Chinese citizens.

- Xerox Corporation has used AHP to allocate nearly $\$ 1$ billion for investigation projects.

- In 1999, it has been used in the automotive industry - Ford Motor Company, in customer satisfaction analysis to increase customer satisfaction to prioritize criteria that serve to improve customer satisfaction. Ford's Excellence Award given to it by Expert Choice Inc. best evidence the quality of this analysis.

- In 1986, the Institute for Strategic Studies in Pretoria, government association, used the AHP to find a quality solution while analysing the conflict in South Africa and proposed actions in the interval from the liberation, of Nelson Mandela to the exemption of apartheid, to civic equality for all races. The results obtained were applied at the state level in that African country. 
- In 1991, IBM used AHP to design the successful mid-range AS400 computer and therefore received the respected Malcolm Baldrige Award for Excellence. Advantages of AHP:

- AHP structures the decision-making problem and successfully simulates the decision-making process from defining the goal, criteria and alternatives, to comparing criteria and alternatives in pairs and obtaining results, i.e. determining the priorities of all alternatives concerning the set goal.

- Decomposes the real decision-making process by decomposing the problem into a hierarchy of elements of that procedure and respects the detail that the person who decides the mental level generally does not separate the process of assessing criteria from alternatives.

- Allows control of the consistency of assessments, taking into account the totality of the problem and functional interactions of criteria and alternatives.

The following is an overview of the findings from the relevant literature.

Xing \& Zhang (2006) analysed the importance of selecting a project manager and qualitatively assessed the competence of the project manager by conducting analysis using triangular Fuzzy numbers.

Rashidi et al. (2011) developed and verified a project manager selection by mathematical model established on the Fuzzy theory of ANNs and Gas. The resulting model could be an interesting replacement option for the traditional approach of project manager selection. To be precise, the information obtained by interviewing was used as input data, and the results obtained by applying this model are very close to the results of the traditional interview that was realized at the beginning of this research.

Subramanian and Ramanathan (2012) provide a very comprehensive overview of the implementation of AHP in the manufacturing industry based on their literature review.

Hadad et al. (2013) proposed model Decision-Making Support System (DMSS) for project manager selection and demonstrate its implementation. The selection criteria were based on their positive references in project management.

Varajao and Cruz-Cunha (2013) for the project manager selection procedure suggest the use of IPMA criteria of the project manager's competence (37 competencies) as relevant criteria for the AHP model. This model can be very effective for decision-makers as it allows comparative analysis of a large number of candidates for the project manager.

Cassar and Martin (2016) used the AHP model in project manager selection in construction taking into account random and fuzzy uncertainties.

Sadatrasool et al. (2016) developed a model for project manager selection for the oil industry. The suggested model called Principle Component Analysis (PCA) is based on a multi-criteria evaluating. This method took into account all important criteria and the weight values for each criterion were obtained by interviewing an experienced group of stakeholders in projects from the oil industry. Model validation was performed by VIKOR method.

\section{Project manager selection in Croatia}

The process of selecting project managers is an insufficiently researched area at the global level and in Croatia where there is no data on any theoretical or empirical research on the mentioned topic. The cause for mentioned is probably because in Croatia the term project is traditionally associated with large infrastructure or engineering activities, so in academic circles, this issue is mainly dealt with at the faculties of civil engineering and not economics (Omazić \& Baljkas, 2005). 
In general, the scientific and professional literature on project management is quite modest in Croatia, where only a few scientific and professional books, textbooks and manuals have been published, for example: Omazić and Baljkas (2005), Buble (2010), Zekic (2010), Radujković et al. (2012) in which the process of selecting project managers is completely peripherally mentioned. The same situation is with the Croatian translation of the university textbook Hauc (2007) and two project management manuals, Horine (2009) and PMI (2011).

One of the scarce Croatian researchers who conduct research related to project management and the role of the project manager is Mladen Radujković - President of the Croatian Project Management Association. Unfortunately, in several of his papers, which he classified in the scientific fields of construction/economics, he only incidentally mentioned the project manager choice, for example: (i) Radujković (2000), an abbreviated description of the process of selecting project managers is given. The author especially emphasizes the need for Croatia's participation in the international project management certification program; and (ii) Radujkovic et al. (2010) defining legal conditions for the realization of construction project management activities, further harmonization of these activities with international practice is nevertheless needed.

Ivas (2019) also mentioned the project manager selection in the context of the legal obligation to appoint a project manager in engineering activities.

Namely, when is the word about project managers in Croatia, there is a certain paradox: on the one hand, in the National Classification of Professions (NN 111/98, 14/2011) the project manager is not listed as a profession, and on the other hand, following the Law on works and activities of physical planning and construction, Article 38 (NN 78/15, 118/18 and 110/19) sectoral investors are obliged to appoint a certified project manager.

There is a major disagreement in attitude related to this topic between the Ministry of Construction, which prescribes the obligation to appoint and certify project managers, and the professional chambers of civil, architectural, electrical and mechanical engineers seeking to abolish these obligations. This requires extensive analysis and goes beyond the scope of this article.

Moreover, from all the above, it is completely clear that the process of selecting project managers is an unexplored area from academic researches and practitioners' aspects in Croatia. The results of this theoretical research can make significant scientific and applicative contributions.

\section{Conclusion}

The aims of this paper are: (a) to provides a useful overview of research on approaches, models, techniques, and competencies during the project manager selection process, (b) to improve understanding and effectiveness of the process of selecting project managers from academic researches and practitioners point of view (c) to make a good framework for future researchers in this under-explored area and encourage researchers to explore this topic; (d) to contribute to the development state of knowledge for this topic and practical implementation in Croatia.

The findings of the relevant literature point to the following:

- The process of selecting project managers is insufficiently researched and it has consequences on the state of knowledge for this topic and at practice, especially in Croatia.

- The project manager is a critical factor in the success of the project and its selection is an extremely complex process with long-term consequences. 
- Both approaches to the selection of project managers have pros and cons and neither is optimal.

- The traditional approach based on the interview is simple, fast, relatively cheap, flexible, but its main drawback is that it is not suitable for a large number of candidates. The opinion of a few types of research is that this approach is ambiguous, biased, and lacking accuracy.

- The modern approach, which is based on mathematical multi-criteria decisionmaking, in addition to the advantages it undoubtedly brings especially with a large number of candidates, also has disadvantages. Namely, in most cases, the multi-criteria models that are applied are general and do not take into account the specifics of the project and the climate. Usually, such models are complicated to apply and are rarely used.

- The situation at Croatia can be described as follow: (a) State of knowledge for this topic is insufficiently researched from academic research aspect. (b)The situation in practice is complex because of the legislation inconsistencies specifically related to the certification of the project manager.

The result of this theoretical research is the proposal of a new approach that is to be a combination of the traditional and modern approach to the selection of project managers. It is a multi-stage approach, which includes the following: (i) the first stage, an initial verification of necessary/required qualifications (qualification, experience, references, certificate); (ii) the second stage, the selection procedure, the so-called selection interview, only for those candidates who have met the first stage enter; (iii) the third stage, the results of the interview would then be processed by one of the models of multicriteria decision making, e.g. AHP); and (iv) the fourth stage, based on the results of multi-criteria decision-making, a decision would be made on the selection of the best candidate.

This new approach can be more effective than the traditional or modern approach but this should be the topic of future research.

Recommendations for future researches: are as following: (i) to design research of project manager certificate validity as the key factor of project manager competency and basic criteria during project manager selection process, and (ii) to design the conceptual research model, optimizing and empirical testing of the new approach proposed by this paper.

\section{References}

1. Afshari, A. R., Nikolić, M., Akbari, Z. (2018), "Review on project manager selection criteria and methods", In 8th International Symposium Engineering Management and competitiveness 2018, 22-23 June, University of Novi Sad, Technical faculty Mihajlo Pupin, Zrenjanin, pp. 3-8.

2. Al-Harbi, K. M. A. -S. (2001), "Application of the AHP in project management", International Journal of Project Management, Vol. 19, No. 1, pp. 19-27.

3. APM. (2015), APM Body of Knowledge (7th ed.), Association for Project Management, Bucks.

4. Aretoulis, G. N., Aretouli, E. N., Angelides, D. C., Kalfakakou, G. P. (2009), "Profiling the modern project manager", In 5th International Conference on Construction in the 21 st Century Collaboration and Integration in Engineering, Management and Technology, 20-22 May, CITC-V, Istanbul, pp. 20-22.

5. Armstrong, M. (2009), Armstrong's Handbook of Performance Management: An Evidence-Based Guide to Delivering High Performance (4th ed.), Kogan Page Publishers, London.

6. Balioti, V., Tzimopoulos, C., Evangelides, C. (2018), "Multi-criteria decision making using TOPSIS method under fuzzy environment", Proceedings, Vol. 2, No. 11, Article 637. 
7. Barnes, M. (1988), "Construction project management", International Journal of Project Management, Vol. 6, No. 2, pp. 69-79.

8. Baykasoğlu, A., Özbakir, L. (2007), "MEPAR-miner: multi-expression programming for classification rule mining", European Journal of Operational Research, Vol. 183, No. 2, pp. 767-784.

9. Boettcher, J. A. (2008), "Ten steps to it project success", available at: www.projectkickstart.com/downloads/IT-projectsuccess.cfm (29 February 2008)

10. Brière, S., Proulx, D., Navaro Flores, O., Laporte, M. (2015), "Competencies of project managers in international NGOs: perceptions of practitioners", International Journal of Project Management, Vol. 33, No. 1, pp. 116-125.

11. Buble, M. (2010), Projektni menadžment (Project Management), Minerva, Dugopolje.

12. Cassar, R., Martin, H. (2016), "How to choose a project manager under uncertainty", In Chan, P. W., Neilson, C. J. (Eds.), 32nd Annual ARCOM Conference (Vol. 2), 5 September, Association of Researchers in Construction Management Manchester, pp. 619-628.

13. Chen, L. S., Cheng, C. H. (2005), "Selecting IS personnel use fuzzy GDSS based on metric distance method", European Journal of Operational Research, Vol. 160, No. 3, pp. $803-$ 820.

14. Clancy, T. (2008), "The Standish group report", avialable at: https://www.projectsmart.co.uk/white-papers/chaos-report.pdf (20 February 2008)

15. Cobb, M. (1995), "Unfinished voyages", oral presentation, 6-9 November, CHAOS University, Chatham.

16. Collins, P. (1998), "Project manager selection and development process", In 29th Annual Project Management Institute Seminar and Symposium, 9-15 October, PMI, Long Beach, California, pp. 119-127.

17. Crawford, L. (2000), "Profiling the competent project manager", Project Management Institute Research Conference on Project Management Research at the Turn of the Millenium, 21-24 June, PMI, Paris, pp. 3-15.

18. Datta, A., Bansal, V., Diaz, J., Patel. J., Reato, D., Bikson, M. (2009), "Gyri-precise head model of transcranial DC stimulation: improved spatial focality using a ring electrode versus conventional rectangular pad", Brain Stimulation, Vol. 2, No. 4, pp. 201-207.

19. Duckstein, L., Opricovic, S. (1980), "Multiobjective optimization in river basin development", Water Resources Research, Vol. 16, No. 1. pp. 14-20.

20. Edum-Fotwe, F. T., McCaffer, R. (2000), "Developing project management competency: perspectives from the construction industry", International Journal of Project Management, Vol. 18, No. 2, pp. 111-124.

21. El-Saba, S. (2001), "The skills and career path of an effective project manager", International Journal of Project Management, Vol. 19, No. 1, pp. 1-7.

22. Faniran, O. O., Love, P., Smith, J. (2000), "Effective front-end project management a key to achieving project success in developing countries" 2nd International Conference Construction in Developing Countries: Challenges Facing the Construction Industry in Developing Countries, 15-17 November, BONCIC, Gabrone, pp. 1-9.

23. Farahani, R. Z., Seifi, S. M., Asgari, N. (2010), "Multiple criteria facility location problems, a survey", Applied Mathematical Modelling, Vol. 34, No. 7, pp. 1689-1709.

24. Frank, T. (2002), The Superior Project Manager, Marcel Dekker, New York.

25. Fraser, C. (1999), "A non-results-based effectiveness index for construction site managers", Construction Management and Economics, Vol. 17, No. 6, pp. 789-798.

26. Gonzales, R. G., Terriquez, V. (2013), "How DACA is impacting the lives of those who are now DACAmented: preliminary findings from the National UnDACAmented research project", available at https://www.americanimmigrationcouncil.org/research/howdaca-impacting-lives-those-who-are-now-dacamented (05 January 2020)

27. Greer, M. (1999), "Planning and managing human performance technology projects", In Stolovitch, H. D., Keeps, E. J. (Eds.), Handbook of Human Performance Technology: Improving Individual Organizational Performance Worldwide, Pfeiff, San Francisco, pp. 96-121. 
28. Hauc, A. (2007), Projektni menadžment i projektno poslovanje (Project management and project business), M.E.P. Consult, Zagreb.

29. Hadad, Y., Keren, B., Laslo, Z. (2013), "A decision-making support system module for project manager selection according to past performance", International Journal of Project Management, Vol. 31, No. 4, pp. 532-541.

30. Hajkowicz, S. (2009), "The evolution of Australia's natural resource management programs: towards improved targeting and evaluation of investments", Land Use Policy, Vol. 26, No. 2, pp. 471-478.

31. Hauschildt, J., Keim, G., Medcof, J. W. (2000), "Realistic criteria for project manager selection and development", Project Management Journal, Vol. 31, No. 3, pp. 23-32.

32. Horine, G. M. (2009), Vodič za upravljanje projektima: od početka do kraja (Project Management Guide: From Start to Finish), Dva i dva, Zagreb.

33. Horner, A. (2010), "Andrew Horner and the fantastic, amazing, magnificent reverse job application", available at: http://www.reversejobapplication.com (31 November 2012)

34. Hsiao, W. -H., Chang, T. -S., Huang, M. -S., Chen. Y. C. (2011), "Selection criteria of recruitment for information systems employees: using the Analytic Hierarchy Process (AHP) Method", African Journal of Business Management, Vol. 5, No. 15, pp. 6200-6208.

35. Hwang, W. Y., Chen, N. S., Dung, J. J, Yang, Y. L. (2007), "Multiple representation skills and creativity effects on mathematical problem solving using a multimedia whiteboard system", Educational Technology \& Society, Vol. 10, No. 2, pp. 191-212.

36. IPMA. (2015), "Individual Competence Baseline: For Project, Programme \& Portfolio Management" (4th ed.), International Project Management Association, Amsterdam.

37. Ivas, M. (2019), "Quality assurance of construction projects in power sector through professional project management", 14. savjetovanje HRO CIGRÉ, 10-13 November, HRO CIGRÉ, Šibenik, pp. 1-10.

38. Tesch, D., Jiang, J. J., Klein, G. (2003), "The impact of information system personnel skill discrepancies on stakeholder satisfaction", Decision Sciences, Vol. 34, No. 1, pp. 107129.

39. Karbassi, A., Nollet, M. J. (2008), "Development of an index assignment procedure compatible with the regional seismicity in the province of Quebec for the rapid visual screening of existing buildings", Canadian Journal of Civil Engineering, Vol. 35, No. 9, pp. 925-937.

40. Korres, G., Goutsos, S., Kostouros, J. (2003), Principles of Project Organization and Management (Vol. 2), Greek Open University, School of Exact Sciences and Technology, Patra.

41. Kosijer, M., Ivić, M., Marković, M., Belošević, I. (2012), "Multicriteria decision-making in railway route planning and design", Građevinar, Vol. 64, No. 3, pp. 195-205.

42. Kwak, Y. H., Anbari. F. T. (2009), "Analyzing project management research: perspectives from top management journals", International Journal of Project Management, Vol. 27, No. 5, pp. 435-446.

43. Lau, K. M., Shen, S. S. P., Kim, K. -M., Wang, H. (2006), "A multimodel study of the twentieth century simulations of Sahel drought from the 1970s to 1990s", Journal of Geophysical Research Atoospheres, Vol. 111, No. D7, pp. 1-9.

44. Loo, R. (2003), "Project management: a core competency for professional nurses and nurse managers", Journal for Nurses in Staff Development, Vol. 19, No. 4, pp. 187-193.

45. Macan, T. (2009), "The employment interview: a review of current studies and directions for future research", Human Resource Management Review, Vol. 19, No. 3, pp. 203-218.

46. Madter, N., Bower, D. A., Aritua, B. (2012), "Projects and personalities: a framework for individualising project management career development in the construction industry", International Journal of Project Management, Vol. 30, No. 3, pp. 273-281.

47. Meredith, J., Mantel, S. (2003), Project Management - A Managerial Approach (5th ed.), John Wiley \& Sons, Haboken.

48. Morris, P., Hough, G. (1987), The Anatomy of Major Projects: A Study of the Reality of Project Management, John Wiley \& Sons, Haboken.

49. Morris, P., Pinto, J. K. (2007), The Wiley Guide to Project Organization and Project Management Competencies, John Wiley and Sons, Haboken. 
50. Muchinsky, P. (1979), "The use of reference reports in personnel selection: a review and evaluation", Journal of Occupational Psychology, Vol. 52, No. 4, pp. 287-297.

51. Muller, R., Turner, J. (2007), "The influence of project managers on project success criteria and project success by type of project", European Management Journal. Vol. 25, No. 4, pp. 298-309.

52. Nahod, M. M. (2014), "Utjecaj kompetentnog upravljanja promjenama na uspješnost građevinskih projekata" (The impact of competent change management on the success of construction projects), Doctoral dissertation, University of Zagreb, Faculty of architecture, Zagreb.

53. Odusami, K. T. (2002), "Perceptions of construction professionals concerning important skills of effective project leaders", Journal of Management in Engineering, Vol. 18, No. 2, pp. 61-79.

54. Omazić, A. M., Baljkas, S. (2005), "Projektni menadžment" (Project Management), Sveučilište u Zagrebu, Ekonomski fakultet, Zagreb.

55. Omidvar, G., Jaryani, F., Zafarghandi, S., Nasab, S., Jam Shidi, J. (2011), "Importance degree of technical competencies based on it project managers' perspective", 2nd International Conference on Education and Management Technology, 19-21 August, IACSIT Press, Singapore, pp. 150-153.

56. Pant, I., Baroudi, B. (2007), "Project management education: the human skills imperative", International Project Management, Vol. 26, No. 2, pp.124-128.

57. Papke-Shields, K., Beise, C., Quan, J. (2010), "Do project managers practice what they preach, and does it matter to project success?", International Journal of Project Management, Vol. 28, No. 7, pp. 650-662.

58. PMI. (2007), A Guide to the Project Management Body of Knowledge Newtown, Project Management Institute, Newtown Square.

59. Radujković, M., Car-Pušić, D., Ostojić Škomrlj, N., Vukomanović, M., Burcar Dunović, I., Delić, D., Meštrović, H. (2012), Planiranje i kontrola projekata (Project Planning and Control), Sveučilište u Zagrebu, Građevinski fakultet, Zagreb.

60. Radujković, M. (2000), "Current profile of project manager in transition economy", SENET Project Management Review, Vol. 1, No. 1, pp.12-17.

61. Radujković, M., Vukomanović, M., Bezak, S. (2010), "Approaches to construction project managers", Građevinar, Vol. 62, No. 7, pp. 623-631.

62. Rashid, T., Faizi, S., Zafar, S. (2018), "Distance based entropy measure of interval-valued intuitionistic fuzzy sets and its application in multicriteria decision making", Advances in Fuzzy Systems, Vol. 2018, Article 3637897.

63. Rashidi, A., Jazebi, F., Brilakis, I. (2011), "Neurofuzzy genetic system for selection of construction project managers", Journal of Construction Engineering and Management, Vol. 137, No. 1, pp. 17-29.

64. Rees, D., Turner, R., Tampoe, M. (1996), "On being a manager and leader", In Turner, J. R., Grude, K., Thurloway, L. (Eds.), The Project Manager as Change Agent, McGraw-Hill, Maidenhead, pp. 99-115.

65. Saaty, T. L. (1980), The Analytic Hierarchy Process, McGraw-Hill, New York.

66. Saaty, T. L., Vargas, L. G. (2006), Decision Making with the Analytic Network Process: Economic, Political, Social and Technological Applications with Benefits, Opportunities, Costs and Risks, Springer, Pittsburg.

67. Saaty, T. L. (2008), "Decision making with the analytic hierarchy process", International Journal of Services Sciences, Vol. 1, No. 1, pp. 83-98.

68. Sadatrasool, M., Bozorgi-Amirib, A., Yousefi-Babadi, A. (2016), "Project manager selection based on project manager competency model: PCA-MCDM Approach", Journal of Project Management, Vol. 1, pp. 7-20.

69. Šarka, V., Zavadskas, E. K., Ustinovičius, L, Šarkiene, E., Ignatavičius, Č. (2008), "System of project multicriteria decision synthesis in construction", Ukio Technologinis ir Ekonominis Vystymas, Vol. 14, No. 4, pp. 546-565.

70. Sivilevicius, H., Zavadskas, E. K., Turskis, Z. (2008), "Multi-attribute assessment of the asphalt mixing plants", in Zavadskas, E., Kaklauskas, A., Skibniewski. M. J. (Eds.), 25th 
International Symposium on Automation and Robotics in Construction, 26-29 June, Technica, Vilnius, pp. 717-729.

71. Sliogeriene, J., Kaklauskas, A., Zavadskas, E. K., Bivainis, J., Seniut, M. (2009), "Environment factors of energy companies and their effect on value: analysis model and applied method", Technological and Economic Development of Economy, Vol. 15, No. 3, pp. 490- 521.

72. Smith, J. P. (2013a), "Trust-building in the construction project delivery process: a relational look ahead tool for managing trust", Doctoral dissertation, Texas A\&M University.

73. Smith, M. (2013b), "Project manager selection: a better way forward", Doctoral dissertation, Information Technology and Electrical Engineering University College, The University of New South Wales at the Australian Defence Force Academy, Canberra, Australia.

74. Stewart, T. (1999), "Project manager: no. 1 career of the future", Fortune Magazine, Vol. 8.

75. Subramanian, N., Ramanathan, R. (2012), "A review of applications of analytic hierarchy process in operations management", International Journal of Production Economics, Vol .138, No. 2, pp. 215-241.

76. Swanson, A. (1964), "Project manager selection: the decision process", Master thesis, Massachusetts Institute of Technology.

77. Tainter, J. A. (2007), "Kolaps kompleksnih društava" (The Collapse of Complex Societies), Jesenski i Turk, Zagreb.

78. Takey, S. M., Carvalho, M. M. (2015), "Competency mapping in project management: an action research study in an engineering company", International Journal of Project Management, Vol. 33, No. 4, pp. 784-796.

79. Tohidi, H., Jabbari, M. M. (2012), "Role of human aspects in project management", Procedia-Social and Behavioral Sciences, Vol. 31, pp. 837-840.

80. Tudela, A., Akiki, N., Cisternas, R. (2006), "Comparing the output of cost benefit and multi-criteria analysis: an application to urban transport investments", Transportation Research Part A: Policy and Practice, Vol. 40, No. 5, pp. 414-423.

81. Tupenaite, L., Zavadskas, E. K, Kaklauskas, A., Turskis, Z., Seniut, M. (2010), "Multiple criteria assessment of alternatives for built and human environment renovation", Journal of Civil Engineering and Management, Vol. 16, No. 2, pp. 257-266.

82. Uhlir, Ž. (2011), "Utjecaj procesa certificiranja projektnih menadžera na razvitak projektnog menadžmenta u Republici Hrvatskoj" (The impact of the project manager certification process on the development of project management in the Republic of Croatia), Master thesis, Faculty of Economics, Zagreb.

83. Varajão, J. J., Cruz-Cunha, M. M. (2013), "Using AHP and the IPMA Competence Baseline in the project managers selection process", International Journal of Production Research, Vol. 51, No. 11, pp. 3342-3354.

84. Wang, E., Chou, H. W., Jiang, J. (2005), "The impacts of charismatic leadership style on team cohesiveness and overall performance during ERP implementation", International Journal of Project Management, Vol. 23, No. 3, pp.173-180.

85. Wen-Yau, L. (2003), "The analytic hierarchy process in project evaluation: an R\&D case study in Taiwan", Benchmarking: An International Journal, Vol. 10, No. 5, pp. 445-456.

86. Wolff, S. (2005), ECI Technical Manual, McClelland Center for Research and Innovation, Philadelphia.

87. Xing, B., Zhang, A. (2006), "Application of fuzzy analytical hierarchy process in selecting a project manager", In Hua, L., Yu-Hong, Y., Peng, Z. (Eds.), 13th International Conference Management Science and Engineering, 5-7 October, IEEE, Lille, pp. 14171421.

88. Yang, I. T., Chou, J. -S. (2011), "Multiobjective optimization for manpower assignment in consulting engineering firms", Applied Soft Computing, Vol 11, No. 1, pp.1183-1 190.

89. Yoon, K. P., Hwang, C. L. (1995), Multiple Atribute Decision Making: An Introduction" (Vol. 104), Sage Publications, Thousand Oaks. 
90. Zavadskas, E. K., Kaklauskas, A., Turskis, Z., Tamošaitienè, J. (2008), "Selection of the effective devellig house walls by applying attributes values determined at intervals", Journal of Civil Engineering and Management, Vol. 14, No. 2, pp. 85-93.

91. Zekić, Z. (2010), "Projektni menadžment" (Project Management), Ekonomski fakultet, Rijeka.

\section{About the author}

Marija Šiško Kuliš works at Croatian company HEP Production Ltd. as a project manager, and at the Faculty of Electrical Engineering, Mechanical Engineering and Naval Architecture in Split (FESB) as a professor. She is a Ph.D. student in the economy at Faculty of Economics, University of Rijeka. Her research interests are project management, quality, water turbine, business economy. The author can be contacted at email: marija.sisko-kulis@hep.hr 